\title{
The Trace of Masculinity in Indonesian Women Politicians Campaign Speech
}

\author{
Sri Suciati ${ }^{1}$, Rustono ${ }^{2}$, Teguh Supriyanto ${ }^{2} \&$ Mimi Mulyani ${ }^{2}$ \\ ${ }^{1}$ Universitas PGRI Semarang, Central Java, Indonesia \\ ${ }^{2}$ Universitas Negeri Semarang, Central Java, Indonesia \\ Correspondence: Sri Suciati. E-mail: srisuciati@upgris.ac.id
}

Received: February 5, 2018

Accepted: March 6, 2018

Online Published: April 19, 2018

doi:10.5539/ass.v14n5p40

URL: https://doi.org/10.5539/ass.v14n5p40

\begin{abstract}
The research was based on the importance of greater involvement of women in the management of the State. This research aims to describe masculine female politician Indonesia campaign speech. In this study used a qualitative approach in the form of Critical Discourse Analysis (CDA) centred on the dismantling of the ulterior motive behind the language that is used to find the real message. The analysis was done to show the representation of the subject. Based on the results of research on speech discourse campaign prospective of Candidate Regent Kutai Kartanegara namely Rita Widyasari found that when women are involved in politics and do the speech of the campaign to attract sympathy glacial, the choice of the language used in speech tends to be masculine. In short, there was a campaign speech masculine woman through adjective apply, the question directly with the affirmative imperative sentence, constructions, the reference quantity (number), the sentence is active, and the presence of herself with the first person singular. The masculine act of campaign speech is applied so that women who tend to be "tough" transformed into a recognized figure of leadership because that assertiveness and straightforwardness in the language used.
\end{abstract}

Keywords: discourse, leadership, assertiveness, straightforwardness

\section{Introduction}

Machiavelli in II Principle (2008) suggests that the political world is a world that is full of intrigue and subterfuge. In the beginning is a path to political competency. Once achieved, political power is transformed into an effort perpetuate power and way of action without borders. Candidates will be fighting and scrambling the influence in ways that sometimes ignore honesty and glory as human beings.

The image of politic that illustrates a complicated and nasty condition become one of a reason for many women doesn't intend herself into the political world. A stereotype of women as "household queen" as well as other things bringing out "mild-tempered" impact on their feeling doesn't have self-confidence involved into the political world that is determined as masculine, tending to dominate and competitive which is suitable for a male. Masculine traits are known for its quality competition and suppression, in contrast, feminine qualities characteristic of peace, safety and togetherness (Shiva, 1989). Women according to Subono (2003:21) were often identified with the subtlety and politeness. As a result, political campaign activities considered most people as an inappropriate activity performed by women. Therefore, women who enter the world of political means must be "willing to be male" and ready to fight in the realm of hard men. The position of women in the political arena is to be modified due to the involvement of women in the management of the country is indispensable. In addition, women also have different political rights with men. Women should be contributing to decision makers and not merely execute decisions. What's more, the total population of women in Indonesia balanced when compared to the male population. Based on the population census of the year 2010 source from (www.bps.go.id), the male population of Indonesia as much as 119,630,913 inhabitants, while the women a number of 118,010,413 inhabitants. The sex ratio is 101 . That means, there are 101 men for every 100 women.

The amount that is balanced between men and women it turns out is not proportional to the representation of women in the legislature. Although based on Constitutional Laws No. 12 in 2003 there is affirmative action quota of $30 \%$ representation of women, but until now only reached $17.7 \%$, even smaller in comparison with the previous period which reached 18\% (Decision. Election Commission No. 146/KPTS/Election Commission may 14, 2014). Do not differ greatly with the condition, based on the record of the Interior Ministry in 2010, of a total 
of 440 positions of Regent/Mayor throughout Indonesia, only $2.27 \%$ run by women (Syafputri, 2014). Meanwhile, of the 33 provinces since 2015 none-sex female Governor after Ratu Atut, Governor of Banten which was replaced by his Deputy, Rano Karno because of a corruption case.

The small percentage of women in the legislature, as well as the head of the area, showed that plenty of women have not been interested in politics. In addition, the fact shows that the Megawati Sukarno Putri up to this time being the only female Indonesia who served as General Chairman of the party in Indonesia, namely the Indonesia Democratic Party of Struggle. In fact, according to Nuryoto (1998:16-24) results showed that academically, women at the various levels of education shows a better achievement than men.

Since the enactment of Constitutional Laws No. 22 in 2007 about organizers of the elections, the election of the district head (elections) are no longer carried out by Regional People's Representative Council known as (DPRD) but rather done directly by the community. In this way, the opportunity of women to run for Office and was elected as a district head are becoming increasingly open.

With direct elections, the popularity of the candidate matters is considered by the poles. Candidates who have high ability General is well known by the public. Therefore, candidates usually strive hard in order to acquaint themselves with the widely known by the public. In this case, the campaign became a powerful way. One form of campaign perspective is often done face to face directly with the community and delivering a speech of the campaign. In a campaign speech contained words, phrases, and sentences are believed to have the power to convince people to drop the selection on a particular candidate. Therefore, the mastery and way of delivery is a good language to the attention of its own in the delivery of the speech of the campaign.

Lakoff (1979), Tannen (1991), and Cameron (1994) suggested that male and women differ in their use of language. In addition to the more assertive, men tend to be more businesslike and rough language compared to women. Women are more careful when expressing something, with a choice of words that are more subtle and polite. Language means tend to be male, while the language of women means more than one, one meaning as it says (explicit) and the other meaning is implicit meaning.

Women are more likely to use said cooperative, while men are more likely to use a competitive style. Girls tend to get appreciation when it can "maintain" her attitude, while boys tend to get the appreciation when able to demonstrate the style of an assertive and authoritative said. This difference according to Tannen (1991) because the guy with the language wants to keep their influence, status, and creating a condition. On the contrary, women are using language for communication and establishment of relationship defending in order to be "frowned upon". Shiva (1989) referred to it as the quality of the feminine and masculine qualities in speaking. Feminine qualities are more likely to be owned by women, while the masculine qualities tend to be owned by males. This means that women also have masculine qualities and vice versa.

It is at the same time also pointed out that the language reflected the culture and thoughts that develop within communities the wearer. Language becomes a set of conventions strategies reflect social relations. One of the important aspects of social relationships within the community is the Division of roles based on gender. In this case, the language is available as a tool to embody those roles. By quoting the opinion of Philips and Moi, Budiman (1992) formulated that contain terms, concepts, and a label that marked all these manners. That is the behaviour of which is appropriate for men and which are improper for women. Language record assumptions that are believed to be by the people regarding how should a man or women looking, thinking, and acting.

How the discourse of female politician campaign speech when the language is used tends to be a stereotyped feminine quality of entry to politics that is considered a masculine quality becomes interesting to be researched.

\section{Method}

As a subject of research is Rita Widyasari hereinafter called RW. RW is a woman who is very well known in its territory, Kutai Kartanegara (hereinafter called as Kukar district. RW election was elected the first female Regent in Kalimantan region, Kertanegara district, through Regional Election in 2010. In December 2015, she was again elected as a Regent for the second period of Kertanegara district.

In this study used a qualitative approach in the form of critical discourse analysis (CDA). This is attention focused on the dismantling of the ulterior motive behind the language used. In this context, it should be noted that in order to found the real message. The analysis is mainly done to show the representation of the subject, namely the candidate Regent of Kukar district, RW election is shown through the language used in the campaign speech titled "The Big Campaign Rita Widyasari and Daman" at Rondong Demang, Tenggarong, on Wednesday, November 25, 2015.

In this study, the framework of Fairclough's CDA is used as the main foundation of research. Basing on 
Fairclough's opinion (1989), the discourse was analyzed from three dimensions that exist simultaneously: texts, discourse and practice, socio-cultural practice; the texts spoken language or writing, practice of discourse, such as the production and interpretation of texts and interpretation/socio-cultural practices, namely the context of communities, institutions, and culture that define the form and meaning of a discourse. Thus, the masculine campaign speech of RW election is analyzed in three dimensions. In this case, the use of language in the speech of the campaign speech RW discourse identified with based on the dimension text. Next, do the prediction and analysis of the data, in accordance with the social context of its culture.

\section{Result and Discussion}

\subsection{Feminism and Masculine Features}

In fact, women and men develop a style of speaking or speech styles are different. Wareing (1999) indicated that male and female separate systemically in important stages of their lives. In childhood and youth, friendship brings men and women from different subcultures especially with regard to rules of behavior and rules of passionate speeches, this effect on the difference in language using and style of speaking among men and women.

Interesting language phenomenon that is found in the speech of the campaign RW election is the use of adjectives, form questions, sentence mode, the reference sentences, verb, and the presence of the self (in the text) as seen in Table 1 the Masculine Language Phenomenon.

Table 1. Masculine Language Phenomenon

\begin{tabular}{|c|c|c|c|}
\hline No. & $\begin{array}{c}\text { Language } \\
\text { Phenomenon }\end{array}$ & Masculine Features & Feminism Features \\
\hline 1. & $\begin{array}{l}\text { Applying } \\
\text { Adjectives }\end{array}$ & $\begin{array}{c}\text { Neutral and not used much } \\
\text { Appearing } 6 \text { adjectives: } \\
\text { - } 2 \text { superlative adjectives " highest" and } \\
\text { "widest" }\end{array}$ & $\begin{array}{l}\text { Adjective "empty" (minor) and frequently } \\
\text { appear. } \\
\text { - } \quad 2 \text { adjectives: "superbly"And "steadily" }\end{array}$ \\
\hline 2. & $\begin{array}{l}\text { Question } \\
\text { forms }\end{array}$ & $\begin{array}{c}\text { Direct question, constructive affirmative } \\
\text { - } 9 \text { direct questions with constructive } \\
\text { affirmative }\end{array}$ & $\begin{array}{c}\text { Rhetorical questions/tag question } \\
\bullet \quad 3 \text { tag questions }\end{array}$ \\
\hline 3. & $\begin{array}{l}\text { Sentence } \\
\text { method }\end{array}$ & $\begin{array}{l}\text { Imperative/ directive } \\
\text { - } \quad 7 \text { interrogative forms }\end{array}$ & 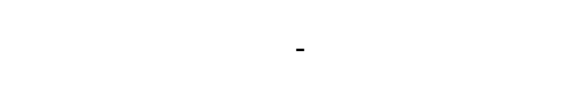 \\
\hline 4. & $\begin{array}{l}\text { Sentence } \\
\text { references }\end{array}$ & $\begin{array}{c}\text { Quantitative } \\
\text { - } 10 \text { numbers refer to amount of } 8 \text { sentences }\end{array}$ & $\begin{array}{l}\text { Qualitative } \\
\text { - } 2 \text { words refers to the amount of a word } \\
\text { "incredible", and word of "all" parties }\end{array}$ \\
\hline 5. & Verb & $\begin{array}{c}\text { Actives } \\
\text { - } \quad 31 \text { active verbs into } 23 \text { sentences }\end{array}$ & $\begin{array}{c}\text { Passives } \\
\text { - } 8 \text { passive verbs into } 4 \text { sentences }\end{array}$ \\
\hline 6 & $\begin{array}{l}\text { The } \\
\text { self-presence } \\
\text { of a speech }\end{array}$ & $\begin{array}{l}\text { The singular pronoun "I" } \\
\text { • Appearing } 14 \text { times }\end{array}$ & $\begin{array}{l}\text { - } \quad \text { Singular plural pronoun } \\
4 \text { words "us" and } 7 \text { words "we" }\end{array}$ \\
\hline
\end{tabular}

The first phenomenon that is used is adjectives form. Lakoff (1979) and Haas (1979) stated that women use the adjectives more often than men. Generally, the use of adjectives by women is doing emotionally. In her campaign speech, a discourse of RW election only turns out using three times the word "superbly", once the word "steadily", once the word "highest" and one time the word "widest". This shows that quantitatively of RW election isn't much use adjectives along the speech that it conveys, though in fact some sentences can be responded with the same adjectives in few sentences of the other. The five adjectives are used, two of which can be categorized as masculine, i.e. "highest" " and "widest", in the sentence "I feel proud and honored today, say the highest and widest award, over the presence of ladies and gentlemen gives tremendous vibrancy to me to build the Kutai Kartanegara in the period of 2016 to 2021 for the support of the whole community of Kutai Kartanegara". Two superlative adjectives are used in order to provide an appreciation to the audiences with a very large number of those present in the great campaign, giving support to the RW as a potential Regent of Kertanegara district. Adjectives are not including category "empty" as explained Lakoff (1979). The adjective does not convey impression idealism or childish or not mature in thinking for its users in the context of that sentence, though there are inaccuracies in the election on the word "existence". The "high" customarily given, but the "wide" is not commonly used.

Other adjectives are used in sentences in all speech of RW election, that the word "superbly" in the sentence " take a walk to Hulu, there's definitely some sponge cake ... If you are interested in advanced select the number ... (one, audiences) .... It is superbly "!. The word "superbly" in that sentence means "great", "unusual", 
"exceptional" or "is not equal to the other". Similarly, the word "superbly" in the sentence "what do need to establish the competency-based human resources in Kutai Kartanegara Regency? (A wish, audiences) ..., it is superbly...! The choice of the word "superbly" in the second sentence, it cannot be said to be "empty" adjectives. It is electrically neutral. However, seen from the "time/time pronunciation", that word is pronounced after the sentence intact (perfect) delivered by a candidate of RW response to the audiences, and she responded with speech "superbly", so it belongs in the category of feminism. Likewise with the word "steadily" in the sentence "what is the need to establish a bureaucratic reform in Kutai Kartanegara Regency? (Need to be), steadily...!!!" The word "steadily" is also a response to the response given audiences. The use of the adjectives "steadily" at sentence meaning "solid and keep it" (no wobble, no change) is also neutral. The use of the adjectives "steadily" at sentence meaning "fixed" solid and (no wobble, unchanged), as the word "superbly" in the previous sentence, including the infantilism category. This word is used to give the appreciation to the audiences who pay attention and understand what the subject is delivered.

There are different things on the adjective "incredible" in the sentence "I feel proud and honoured today, say the extended award, widely over the presence of ladies and gentlemen all who give incredible spirit on me to build Kutai Kartanegara in the period of 2016 to 2021. The word "incredible" is neutral and is used in the sentence so that it does not include the infantilism category. Thus, three of the adjectives used in the form of the answer to the question the subject of the response given by the previous subject more serves as a "senggakan" (javanese=support) capable of creating an intimate atmosphere/warm so that the categories include the feminine. Meanwhile, the word "highest", "widest" and "incredible" used blending in a sentence does not include the feminin category of infantilism. The selection of adjectives or adjective in the speech campaign of RW election as well as the placement in the sentence implies the look explicit and strong as a candidate for Regent and they are able to create a warm atmosphere.

The second phenomenon is the use of question form. It is generally marked with the word question particle or "question-tags" attached to verbs. The form of the question used to obtain responses or answers from those who asked. In her campaign speech, the candidate of RW uses many interrogative sentences, generally in the form of a direct question in sentence construction of affirmative (direct question affirmative construction). Recorded the candidate of RW use 9 (nine) in this type of questions, given in the form of a question that contains a designation, edification, reinforcement, or a positive assertion about something. The sentence is marked with the word question "what" at the beginning of each sentence and is followed by a selection of that assert the words of affirming/affirmations such as "stabilize" in the sentence "what is the need to stabilize bureaucracy reform in Kutai Kartanegara Regency?", the word "increase" in the sentence "what is the need to increase agricultural, tourism management for the Group of economic structure in the massif of Kutai Kartanegara Regency?", the word "build" in the sentence "what do we need to build infrastructure for the sake of power interconnection competitive area in Kutai Kartanegara Regency?, and the word "what" as in the phrase, "what do we need to do a women's empowerment and strengthening child protection in Kutai Kartanegara Regency? On sentences that look that all questions submitted directly in the construction of the affirmative. According to Baikalova (2016), direct question affirmative construction is more widely used in the masculine features.

In addition, the candidate of RW in a campaign speech also use question tag marked by a word like "isn't it" such as in the sentence "Rita-Edi comes to represent all of ethics in Kutai Kertanegara district, isn't it?, to represent all of religions in Kutai Kertanegara district, isn't?, to represent all of professions in Kutai Kertanegara, isn't it?". The word of "isn't it" that is conveyed with question form in the sentence stated can be lined up with "question tag". This sentence conveyed not for getting an answer or rhetorical term in the order it is called by rhetorical question. Question tag according to Baikalova (2016) or than applied by women and believed containing feminism quality. While, compared with direct question form in the affirmative construction, the using of question tag much less using.

The third phenomenon is sentenced method. It relates to ideas expressed to partner or others (Santoso 2003:175). Those ideas can be expressed in declarative, interrogative, and imperative forms. Compared with a declarative and imperative sentence, the imperative sentence is applier into speech campaign of RW election. The presence of an interrogative sentence is marked by the imperative verb "choose" in the sentence "... .. Select number one ... imperative verbs", "pass" in the phrase "tell who is not present today ...", imperative verbs "choose" in the phrase "choose a Regent of existing female", and said the final command "please" in the sentence "... we ask to forward" and "... Please forward everyone". If these last two sentences delivered by the candidate of RW to the figure (party officials) are respected, while the verb "choose", "pass", and "hold" presented to audiences and communities of Kutai Kartanegara in General. The interrogative sentence is used with the hopes of responded with actions as instructed. In this case, the candidate of RW as an addresser is the subject of "request" or 
"command" something to the people or certain parties to do something. Thus, the candidate RW, in this case, takes the position as the giver of command to other people/caller/audience. A large of an imperative in discourse mode shows a campaign speech it conveys masculinity.

The fourth phenomenon is the reference to sentences in the form of quantity numbers. Everyone has certain tendencies in the speech that it conveys. Some people are predisposed adverbial, explanatory words, some others use quantity figures. In her campaign speech, there are a lot of candidate of RW many use quantitative references (numbers) in its words. At least 10 (ten) words that refer to numbers is presented in 8 (eight) sentences that are all pointing at the amount. The word "seven" in the sentence "there is 7 necessity we have to perform in the King's Gate the second volume, yes...There are 7 missions that I have to convey". The word "one" in the sentence " 1 laptop, 1 teacher, 1 house for teachers who do not yet have a house ...", the word "hundred million" in the sentence "Each group of farmers and fishermen will be given 100 million annually". The word "three percent" in the sentence "we will set aside a budget of at least $3 \%$ so that the bore, check out pregnancy in Kutai Kartanegara Regency is free to all regions, the words "ten percent" in the sentence "we are also committed to set aside $10 \%$ of budget funds GRANT of Kutai Kartanegara district". Similarly, the words "of up to twenty-five million five hundred million" in the sentence "we are also committed to providing credit to women without monetary, without any guarantee, of 25 million to 500 million for all women in Kutai Kartanegara district.

Number or a Word Number bookmark such as "seven", "one", "hundred million", "three percent", "ten percent", "twenty-five million", and "five hundred million" at the sentences above become the sign of the certainty of the amount of something called for by the subject According to Wood (2009), the man with masculine qualities are marked with the reference number that is considered to be exact. With reference numbers on the use of the phrase, surely the impression and "be counted" as well as logical became very evident. Quantity/number is considered to be definitely for men so are considered more masculine (Wood 2009).

Even so, words/phrases with references on the approximate amount were also used by the candidate of RW though not as much as a quantitative reference. The phrase "incredible large number" in the sentence "the incredible large number I feel proud and honored today, say the highest and widest award over the presence of ladies and gentlemen all" and the word "all" in the sentence "Although we are the independent but we also supported not carried on Yes ... I carried on by the people but supported by all parties that existed in Indonesia. The word "incredible" in two sentences above refers to the total number of (people who attended the high campaign of RW candidate) that very much. Similarly, to refer to the number of parties that support her, a candidate of RW uses the word "all". This presents both qualitative words feminine side than the language used by a candidate of RW.

Active and passive forms of are the next phenomenon. According to Irigaray (2005), a person's courage in expressing opinions is characterized by the use of an active sentence as well as the appearance of subjectivity. In her campaign speeches, a candidate of RW dominant use Active sentence could even say "almost" doesn't use a passive sentence to say "how lack". Active sentences that are characterized by the use of active verbs such as "feel", "say", "build", "support", "select", "set aside," and so on, as in the sentence "we are also committed to set aside $10 \%$ of budget funds budget of Kutai Kartanegara for agriculture" and the phrase "we are also committed to the youth to make independent youth clinics so that youth do not think how to find work but how to open employment. This means that courage which is identical with one's masculinity also became an identity candidate of RW. With verbs and sentences is active, the discourse of her campaign speech to be more masculine.

Meanwhile, the use of passive sentences found only a few long speeches. The presence of a passive sentence is marked with passive verbs, such as the word "given" in the sentence "Each group of farmers and fishermen will be given 100 million annually" and passive verbs "supported" and "carried" in the sentence "I was carried by the people, supported all the existing parties in Indonesia". This shows that in addition to demonstrating the quality of the masculine, the feminine also performed by a candidate of RW is sentence passive in her campaign speech discourse.

The next phenomenon is the presence within the discourse of campaign speeches. Politicians are presenting themselves in a speech before a specific strategy with an audience. This is apparent through the selection of the form of pronominal persona in the speech of the politician's campaign. Self-implicate the presence of options strategies against social distance created between politicians and audience. The use of the word "we" or "our" give effect closer or intimate in comparison with the word "I". In her campaign speeches, the candidate of RW discourse more use of pronouns "I" rather than "we" or "us". The word "I", among others, appear in the sentence "ladies and gentlemen of all who $I$ respect, there are 7 missions that $I$ have to pass. ..I am proud to present this 
day once here in front of me this present great figure. $I$ wanted to call out one by one,... There are also presented my champion, Secretary General of Golkar's Party namely Bang Idrus. ...the incredible spirit of giving to me to build Kutai Kartanegara.

It is shown in that quote that candidate of RW is presenting herself as the first singular person. At least fourteen times that candidate of RW using the pronouns "I", while the first person plural "we" is used seven times and "we" four times. According to Xia (2013) in speaking, women tend to use the first plural pronouns, whereas men tend to use the pronouns of the first single. This shows that when women are more use of pronominal first single means she shows a quality of masculine in speaking.

In the context of a campaign speech, the candidate of RW use pronouns "I" in accordance with the rules of the normative use of pronouns. On the other hand, the dominance of the choice of pronouns "I" also show a masculine "strength" the subject because even though as a candidate but also as the place the single Regent position which has the "power" and a big name in front of "her community", Kutai Kartanegara district community. That is, it has a high popularity, a candidate of RW is very well known and respected by the community, as a Regent.

\subsection{Masculine Discourse: An Explanation}

Based on the above data analysis exposure can be expressed that the candidate of RW in a speech campaign attempts to appear masculine in the language that is used. The masculine is used as standard size because of the world leader in patriarchy identical to men so that the image of the great women almost always refers to something commonly done/said by a female. A great image for its candidate of RW, empowering words or language that are considered more masculine than feminine language superior were considered inferior. Based on this phenomenon, masculinity being an ideology that dominates and hegemony to borrow a term used Gramsci (1971) even though the actual good qualities of masculine or feminine are equally important, it takes in the life in the portion the same great. The ideology of the hegemony is the climax of a series of idea or capability of the group in power to influence the overall elements that exist in the community. The hegemony ideology that created a mass submission "spontaneous" is toward ideas or values of the dominant group (Gramsci, 1971; Kusujiarti, 2003).

Girls, as well as boys, are treated in ways that are systematically different. They have different experiences at home, at school, and at work. They worked on the different things while expecting the difference will come from them. Women since childhood culturally prepared for working in the domestic sphere, while male since childhood prepared as a leader with a public activity. When a woman, candidate of RW was about to "cross-over" into the land of men (public), she uses the standard male in order to be accepted and recognized or otherwise considered worthy being a leader. The language, in this case, becomes one of the means to strengthen that role.

"Resolute" and "strong" is the quality culturally prepared to "house leader" such as men. Assertiveness and strength it is also reflected in a choice of words and sentences. Not surprisingly, when a Regent or candidate of female RW delivered a campaign speech in front of communities in Kutai Kartanegara, she did not want to get the attribute or predicate as leader of "women" is weak. Therefore, the choice of adjectives, questions form, sentence mode, the reference sentences, verbs and pronominal as a form of self-presence in the discourse of campaign speeches all tend to be masculine.

Adjectives are "neutral" and not influence, the questions from directly and affirmatively as well as minimize the question tag, be an option. In addition, the dominant imperative sentence mode shows a side of campaign speech discourse masculinity of other RW. The explanation is that the power to give instructions or commands generally done by the person who has the authority to give orders. She has the "power" to give the orders. In this case, the public role as a leader of the culturally is identified with men manifested through the using of an imperative sentence. This implies the appearance of campaign speech discourse RW as a potential Regent woman is manly. In other words, the image of a leader that is obtained through the use of the masculine sentence commands/instructive.

Reference sentence if quantitatively in figures in campaign speech discourse is masculine of RW's candidate to another. Reference this number by Wood (2009) are masculine because of the certainty of the amount can be calculated (exact). This contrast such as with long purely qualitative explanation is more likely to be considered feminine. Emergence numbers evenly in almost every campaign speech became a part of the discourse marker idiosyncrasies of speech is a man. Another masculine is the use of active verbs and sentence. The form of the verbs and active sentences that dominate the use of the phrase in the campaign speech of RW's candidate show courage and aggressiveness of the women who had been considered likely to be the male's territory. The use of 
active form at the same time also marked the appearance of identity and subjectivity of the subject.

The next masculine is the attendance of the self through the use of a pronominal first single "I" called by Baikalova (2016) as masculine features. Use of the pronouns "I" shows the confidence of RW's candidate. The single candidate as RW certainly understands well the community needs of Kutai Kartanegara during the last four years were under her direction. He was also sure of what to do if served as a regent for the second time. In addition, confidence also woke up because its presence (in the high campaign) as Regent of Kutai Kertanegara district (single candidate) gives a sense of pride for an audience because equally with a supreme leader in its region, listened to the speech of the campaign, and even be shaken with her. On the other hand, the use of the first person singular pronoun "I" also showed a distance between the politicians with the audience. The word "I" implies domination or power, bony self, who is more instrumental. Campaign speech, in this case, was indeed carried out by RW's candidate, but it surely comes as part of a pair of an aspiring candidate of Regent and Deputy of Regent.

Based on the explanation above, the exposure can be expressed that to enter and engage in the political world is loud and full competition (masculine) women who tend to be feminine must use the standard masculine male. In other words, the necessary masculine process of speech campaign through various linguistic features, so that the prospective women leaders are not considered weak "as women" who tend to be more feminine. So, it can be expressed that the description of the great female referred to on something that could be done by men. Even Ward (Lee, 1992:111) says that all people are male unless women can prove it. As a result, women have to out of the world of "feminism" which is feminine in order to seize the opportunity and the position with the size of the masculine that glorifies competition and aggressiveness.

Nevertheless, it should be expressed that not every linguistic feature used the subject of masculine quality. In the discourse is also found, although the amount is not much, adjectives infantry, question tags, first plural pronouns and references are predisposed qualitative feminine. This shows that the linguistic features with any feminine qualities desperately needed in developing a discourse of a good campaign speech. Can even put forward that the feminine qualities that tend to "embrace" and "engaging the community" through the intimate atmosphere of the warm/created (through feminine linguistic features are used) to be important things to watch out for.

Use of the pronouns "we", for example, which implies the involvement of audience or opponents talk tends to be more rarely used. In the context of the campaign carried out in the framework of the "embrace" to get much support from the public, first plural pronouns thus need to be more empowered. Pronouns "we" have the power to make audience became part of the program and the steps the candidate of regent motion. Likewise with the words "support" in the form of adjectives infantry immaturity in "support" thus being able to create an atmosphere of intimate and warm so that it is between addresser with audience be "not located". The same empowerment can also be done for question tags. Rhetorical question or questions that are submitted for the purpose of obtaining a conviction upon it presented the subject also implies closeness between addresser with an audience who "feel" the public opinion (entangled) about something.

Thus, it can be expressed that linguistic features of masculine or feminine are two things that are required in the discourse of speech campaign prospective candidate leaders of Indonesia. Women should not feel lowly with her feminity, and men did not need to be higher because of his masculinity. Related to this Tong (2006) argued that women are capable of creating their own, without gender-neutral language associating and the language of men. The femininity of women as identity thus became the hallmarks of creating life balance.

\section{Conclusion}

Women are generally depicted as creatures with domestic role stereotypes courtesy and manners are, among others, are characterized by the use of language that is likely to be feminine. In this study, it was found that when women are involved in politics and do the campaign speech to attract the sympathy of the public, she turned out to be masculine. The choice of language that is used in speech tends to be masculine. In short, there was a campaign speech masculine of women through the use of adjectives, the question directly with the affirmative imperative sentence, constructions, the reference quantity (number), the active sentence, the presence of the self with the first person singular, and the choice of topic. Masculine campaign speech did so that women who tend to be "gentle" was transformed into a recognized figure of her leadership because of assertiveness and straightforwardness in the language used.

\section{Acknowledgements}

In the Name of God, I am willing to present my gratitude to everyone who has helped me, especially in this research paper and I want to thanks to my object correspondence; my Rector in Universitas PGRI Semarang, 
Indonesia; my beloved family and child. May God will be blessing my research paper and kindness.

\section{References}

Baikalova, S. N. (2016). Gender Features in Female Political Discourse: The Construction of Hillary Clinton's Political Image. Journal of Siberian Federal University. Humanities \& Social Sciences, 1-9. (No.1-8)

Budiman, K. (1992). Subordinasi Perempuan dalam Bahasa Indonesia. In Budi Susanto S. J. et al., Citra Wanita dan Kekuasaan (Jawa). Jakarta: Kanisius.

Cameron, D. (1994). Feminism \& Linguistic Theory. London: Macmillan.

Fairclough, N. (1995). Critical Discourse Analysis: The Critical Study of Language. Harlow-Essex: Longman Group Limited.

Gramsci, A. (1971). Selections from the Prison Notebook. London: Lawrence and Wishart.

Haas, A. (1979). Male and Female Spoken Language Differences: Stereotypes and Evidence. Psychological Bulletin, 86(3). https://doi.org/10.1037/0033-2909.86.3.616

Irigaray. (1985). Luce. Speculum of the Other Women. Translated by G. C. Gill. New York: Cornel University.

Kussujiarti, S. (2003). Antara Ideologi dan Transkrip Tersembunyi Dinamika Hubungan Gender dalam Masyarakat Jawa. In I. Abdullah (Ed.), Sangkan Paran Gender (Cetakan 2). Yogyakarta: Pustaka Pelajar.

Lakoff, R. (2004). Language and Woman's Place: Text and Commentaries. Oxford University Press.

Lee, D. (1992). Competing Discourses: Perspectives \& Ideology in Language. London \& New York: Longman.

Marchiavelli, N. (2008). Il Principle. Translated by Dwi Ekasari Aryani. Yogyakarta: Narasi.

Nuryoto, S. (1998). Perbedaan Prestasi Akademik antara Laki-laki dan Perempuan. Studi di Wilayah Yogyakarta. Jurnal Psikologi, 2, 16.

Santoso, A. (2013). Bahasa Politik Pasca Orde baru. Jakarta: Wedatama Widya Sastra.

Shiva, V. (1988). Staying Alive: Women, Ecology and Survival in India. London: Zed Books.

Subono, N. I. (2013). Perempuan dan Partisipasi Politik. Jakarta: Yayasan Jurnal Perempuan.

Syafputri, E. (2014). Keterwakilan Perempuan di Parlemen: Komparasi Indonesia dan Korea Selatan. Indonesian Journal of International Studies, 1(2), December.

Tannen, D. (1987). Gender and Discourse (p. 240). Oxford University Press.

Tong, R. P. (2006). Feminist Thought: A More Comprehensive Introduction. Translated by Aquarini Priyatna Prabasmoro. Yogyakarta: Jalasutra.

Undang-Undang No. 12 Tahun 2003 tentang Pemilihan Umum Anggota Dewan Perwakilan Rakyat, Dewan Perwakilan Daerah, dan Dewan Perwakilan Rakyat Daerah.

Wareing, S. (1999). Language and Gender. In L. Thomas, \& S. Wareing (Eds.), Language, Society and Power: An Introduction. London \& New York: Routledge. https://doi.org/10.4324/9780203426968_chapter_5

West, C., \& Zimmerman, Z. H. (1987). Doing Gender. Gender \& Society, 1(2), 125-151. https://doi.org/10.1177/0891243287001002002

Widyasari, R. (2015). Kampanye Akbar Rita-Daman. Transliteration.

Wood, J. T. (2009). Gender. In 21st Century Communication: A Reference Handbook (pp. 368-380). Thousand Oaks, CA: SAGE. https://doi.org/10.4135/9781412964005.n41

www.bps.go.id. (2010). Hasil Sensus Penduduk Tahun 2010.

www.youtube.com/watch?v=uPGPiZwbtdg. Kampanye Akbar Rita Widyasari \& Daman.

Xia, S. (2013, August). Gender Differences in Using Language. Theory and Practice in Language Studies, 3(8), 1485-1489. https://doi.org/10.4304/tpls.3.8.1485-1489

\section{Copyrights}

Copyright for this article is retained by the author(s), with first publication rights granted to the journal.

This is an open-access article distributed under the terms and conditions of the Creative Commons Attribution license (http://creativecommons.org/licenses/by/4.0/). 